\title{
The Effect of Ensiling Sugar Beets on Preservation Characteristics, Nutrient Profile, and in Situ Disappearance
}

\author{
Ian R. McGregor \\ Klamath Basin Research \& Extension Center, Oregon State University \\ 6923 Washburn Way, Klamath Falls, OR 97603 \\ Tel: 1-541-883-7131_E-mail: ian.mcgregor@oregonstate.edu \\ Jan G.P. Bowman \\ Dept. of Animal and Range Sciences, Montana State University \\ PO Box 172900, Bozeman, MT 59717-2900 \\ E-mail: jbowman@montana.edu
}

\section{Chad M. Page}

Dept. of Animal Science, University of Wyoming

1000 East University Avenue, Laramie, WY 82071

Tel: 1-602-615-5952_E-mail: cmpage18@gmail.com

\author{
Ashton Hubbard \\ Dept. of Animal and Range Sciences, Montana State University \\ PO Box 172900, Bozeman, MT 59717-2900 \\ Marley Manoukian \\ Dept. of Animal and Range Sciences, Montana State University \\ PO Box 172900, Bozeman, MT 59717-2900 \\ E-mail: marleymanoukian@gmail.com
}


Whitney C. Stewart

Dep.t of Animal Science, University of Wyoming

1000 East University Avenue, Laramie, WY 82071

Tel: 1-307-766-5374Ｅmail: whit.stewart@uwyo.edu

\author{
Megan L. Van Emon (Corresponding Author) \\ Dept. of Animal and Range Sciences, Montana State University \\ PO Box 172900, Bozeman, MT 59717-2900 \\ Tel: 1-406-874-8286_E-mail: megan.vanemon@montana.edu
}

Received: June 11, 2020 Accepted: July 7, $2020 \quad$ Published: July 20, 2020

doi:10.5296/jas.v8i4.17165 URL: https://doi.org/10.5296/jas.v8i4.17165

\begin{abstract}
The objective of this project was to determine if sugar beets could be ensiled with hay or soybean meal with or without a liquid mold inhibitor and the impact on nutrient composition, $\mathrm{pH}$, and aerobic stability. A $3 \times 2$ factorial experiment where hay (control; $\mathrm{H}$ ) or sugar beets mixed with either hay $(\mathrm{SBH})$ or soybean meal (SB) were ensiled at a rate of 50:50 (as fed) without the mold inhibitor. The mold inhibitor (T) was included to create three additional treatments: HT, SBT, and SBHT. All treatments decreased in $\mathrm{pH}$ over time $(P<0.01)$, with the lowest $\mathrm{pH}$ value being generated by the SB treatment. Concentrations of NDF increased between $\mathrm{d} 0$ and $\mathrm{d} 90$ for treatments SB and SBT $(P \leq 0.01)$ and increased between $\mathrm{d} 90$ and d 180 for treatments H, HT, SBH, and SBHT $(P \leq 0.01)$. Concentrations of ADF also increased among all treatments $(P \leq 0.05)$. Concentrations of $\mathrm{CP}$ increased from d 0 to $\mathrm{d} 90$ for HT and SB treatments $(P \leq 0.01)$, increased from d 90 to d 180 for the SBT treatment $(P \leq$ $0.02)$, increased from d 0 to $\mathrm{d} 180$ for the SBH treatment $(P \leq 0.03)$, and decreased from $\mathrm{d} 90$ to $\mathrm{d} 180$ for the SB treatment $(P \leq 0.01)$. The data suggests that sugar beets may be ensiled with hay or soybean meal, with or without a liquid mold inhibitor, without negatively impacting nutrient quality or preservation characteristics of the ensiled mixture.
\end{abstract}

Keywords: aerobic stability, digestibility, nutrient composition, $\mathrm{pH}$, silage, sugar beets

\title{
1. Introduction
}

Montana was the 5th largest producer of sugar beets in the United States in 2015 (USDA, 2015a). Approximately 20.5 million kilograms ( $\mathrm{kg}$ ) of sugar beets were left unharvested after the 2014-2015 Montana sugar beet harvest (USDA, 2015b). This typically results in the sugar beets being left in the field and plowed under. Providing additional outlets for these 
unharvested sugar beets may be more economical for sugar beet producers by providing an additional source of revenue as a feed source for livestock.

With this many sugar beets being left in the field, and their substantial energy content ( $81 \%$ TDN; Lardy and Schafer, 2008), sugar beets make an excellent alternative energy source for ruminant livestock. Previous research has indicated that whole shredded sugar beets can replace barley up to $45 \%$ of the dry matter in total mixed rations without having any deleterious effects on steer backgrounding performance or sheep nutrient metabolism (McGregor et al., 2016, 2017). However, the seasonal availability of sugar beets may provide quantities of sugar beets that are too large for immediate use. Additionally, challenges exist when storing sugar beets due to their high moisture content and the high ambient temperatures in September, which reduce the storage viability of sugar beets. Moreover, drying sugar beets can be labor intensive; therefore, ensiling may be a more practical alternative to prevent deterioration. However, little research has been conducted with ensiling sugar beets, much of the research has utilized sugar beet pulp.

Sugar beets contain a substantial amount of available energy (Lardy and Schafer, 2008), and available energy has been demonstrated to decrease the $\mathrm{pH}$ of a silage mixture (Owens et al., 1999). A rapid decline in $\mathrm{pH}$ is the most effective way of inhibiting the enzymes that degrade protein, energy, and fiber throughout the ensiling process (Dewar, 1963; McKersie, 1981; Owens et al., 1999). Therefore, the objective of this study was to determine if sugar beets could be ensiled with hay and soybean meal with or without a liquid mold inhibitor, and the impact of ensiling sugar beets on nutrient composition, $\mathrm{pH}$, and aerobic stability. We hypothesized that sugar beets can be effectively ensiled with other feedstuffs without inducing deleterious effects on nutrient quality or preservation characteristics.

\section{Materials and Methods}

\subsection{Treatments and Storage}

Sugar beets utilized in this study were obtained from the Southern Agricultural Research Center in Huntley, MT (45.924810, -108.244700). Sugar beets were transported to the Bozeman Agriculture Research and Teaching Farm in Bozeman, MT (45.662068, -111.073504). All storage procedures were conducted at the Bozeman Agriculture Research and Teaching Farm. Sugar beets were ground utilizing a woodchipper to reduce particle size for accurate packing to achieve optimal density.

A 3 x 2 factorial experimental design was utilized in our study with the following treatments: hay without the mold inhibitor $(\mathrm{H})$; hay with the mold inhibitor $(\mathrm{HT})$; sugar beets mixed with hay, without the mold inhibitor (SBH); sugar beets mixed with hay, with the mold inhibitor (SBHT); sugar beets mixed with soybean meal, without the mold inhibitor (SB); sugar beets mixed with soybean meal, with the mold inhibitor (SBT). All feed ingredients were mixed at a rate of 50:50 (as fed). Sugar beets were coarse ground with a flail chopper designed for woody biomass. A liquid mold inhibitor (Ultra CURB®; Kemin Industries, Inc.) was added $(0.001 \mathrm{~kg} / \mathrm{kg}$ silage mixture) to the treatments that included the mold inhibitor. Treatments were mixed using a horizontal auger feed mixer (Model 84-8, Roto-Mix®, Dodge City, KS), 
and water was added to each mixture to achieve an optimum dry matter concentration for ensiling (35\%), and to ensure consistent moisture content among treatments.

Mini-silos were created by lining a 3.8-liter bucket with three 45-liter plastic bags. Approximately $4.6 \mathrm{~kg}$ of each treatment was placed in each mini-silo, with a HOBO pendant temperature data logger (Model UA-002-64, Onset Computer Corp., Bourne, MA) placed in the center. A pneumatic air-pump (Air Cadet ${ }^{\circledR}$, Cole-Parmer Instrument Company, Chicago, IL) was used to remove oxygen from each mini silo, once completed, bags were closed and the lid was secured. There was also a HOBO pendant temperature data logger placed outside of the mini-silos in order to record the ambient temperature. Each HOBO pendant temperature data logger was set to record temperature every 15 min.

\subsection{Sampling and Laboratory Analysis}

Samples were collected from the freshly mixed treatments on d 0. Mini-silos were opened and visually inspected for mold on d 90 and 180 of the ensiling process. Mold was not present for any of the treatments. Three mini-silos were allocated per treatment per time-point $(\mathrm{n}=36)$. Samples $(2,000 \mathrm{~g})$ were collected from each mini-silo at each time point and stored at $-20^{\circ} \mathrm{C}$ for further analysis. Five-hundred grams of each sample were dried in a $60^{\circ} \mathrm{C}$ forced air oven for $48 \mathrm{~h}$ to determine DM concentrations. Samples were ground to pass a $2 \mathrm{~mm}$ screen using a Wiley mill (Thomas Scientific, Swedesboro, NJ) and composited by treatment by sample day. Samples were then analyzed for NDF (AOAC, 2005) and ADF (AOAC, 2005) by using an Ankom 2000 Fiber Analyzer (Ankom Co., Fairport, NY). Alpha-amylase and sodium sulfite were used in the NDF procedure. Nitrogen concentrations were also analyzed (AOAC, 2010).

Fresh $50 \mathrm{~g}$ samples from each mini-silo were composited by treatment by day. A $50 \mathrm{~g}$ sample from each treatment was individually homogenized with $500 \mathrm{~mL}$ of deionized water using a Waring blender for $2 \mathrm{~min}$. The resulting homogenized mixture was then filtered through two layers of cheesecloth and analyzed for $\mathrm{pH}$, as described by Cherney et al. (2004).

HOBO pendant temperature data loggers remained at a depth of $10 \mathrm{~cm}$ in the remaining silage for 10 days following the opening of the mini-silos in a climate controlled $\left(19^{\circ} \mathrm{C}\right)$ room, and recorded temperature measurements every $15 \mathrm{~min}$. Mini-silos remained open to mimic the period of time where silos are open and contents are exposed to oxygen during feeding. Minimum and maximum temperatures, as well as how many hours transpired between the minimum and maximum temperatures were recorded. The rate of change in temperature was calculated $\left(\Delta^{\circ} \mathrm{C} / \mathrm{h}\right)$.

\subsection{In Situ Digestibility}

Four cannulated heifers, consuming a grass hay diet, were used to determine the digestible DM content of each silage treatment at each time-point of the ensiling process. Samples were dried in a forced air oven at $60^{\circ} \mathrm{C}$ for $48 \mathrm{~h}$ and ground to pass a $2 \mathrm{~mm}$ screen using a Wiley mill. Five grams of each sample was placed into 10 x $20 \mathrm{~cm}$ Dacron bags (Ankom Technology, Macedon, NY) in duplicates. Bags were soaked in $39^{\circ} \mathrm{C}$ water for 15 min prior to placing bags in the rumen of each cow. The number of hours that each treatment stayed in 
the rumen are as follows: $\mathrm{H}$ and HT bags were analyzed at $0,6,12,24,48,72$, and $96 \mathrm{~h}$; SBH and SBHT bags at $0,2,4,6,12,24,48,72$, and $96 \mathrm{~h}$; SB and SBT bags at $0,2,4,6,12,24$, and $48 \mathrm{~h}$; and a hay standard was included at $0,2,4,6,12,24,48,72$, and $96 \mathrm{~h}$. Zero-hour bags were soaked for $15 \mathrm{~min}$ in $39^{\circ} \mathrm{C}$ water. Each bag was removed at their respective time-points and immediately placed in ice water to inhibit microbial activity. The bags were then rinsed until the runoff ran clear, dried at $60^{\circ} \mathrm{C}$ for $48 \mathrm{~h}$ in a forced air oven, then the bags were weighed and disappearance from each bag was calculated.

\subsection{Statistical Analysis}

The MIXED procedure of SAS (SAS 9.4; SAS Inst. Inc., Cary, NC) was used for the statistical analysis of aerobic stability and change in nutrient composition over time as a $3 \times 2$ factorial. Individual mini-silo served as the experimental unit. Treatments were in triplicates for each time-point observed, with day serving as the fixed effect. Mold inhibitor and replication served as the random effects. In situ disappearance results were also analyzed using the MIXED procedure of SAS with the interaction of inoculant treatment $\mathrm{x}$ day $\mathrm{x}$ hour serving as the fixed effect. Individual bag served as the experimental unit, with two bags for every hour per treatment. Cow and silage opening date served as the random effects. Repeated measures were used to determine treatment differences with the spatial exponential covariance structure, with the subject of heifer $\mathrm{x}$ mold inhibitor $\mathrm{x}$ silage opening day. Significance was set at $P \leq 0.05$, with tendencies set at $P \leq 0.10$.

\section{Results and Discussion}

Nutrient composition and $\mathrm{pH}$ are represented in Table 1 . The $\mathrm{pH}$ of all treatments fell below 5.0 by d $90(P<0.01)$. However, on a numerical basis, it should be noted that $\mathrm{H}$ and HT treatments produced the higher $\mathrm{pH}$ values, $\mathrm{SB}$ and SBT treatments produced the lowest $\mathrm{pH}$ values, with SBH and SBHT treatments being intermediate. The SB treatment also demonstrated the most rapid $\mathrm{pH}$ decline among all un-treated silages. This observation is in agreement with Ferris and Mayne (1994) as well as Moore and Kennedy (1994), who observed that ensiling unmolassed sugar beet pulp with perennial ryegrass decreased $\mathrm{pH}$ as the unmolassed beet pulp was added to the silage mixture. Leupp et al., (2006) demonstrated that wet sugar beet pulp has a strong influence on $\mathrm{pH}$, as the $\mathrm{pH}$ remained constant among various levels of DM when ensiled with dry pelleted beet pulp, dry rolled corn, wheat midds, and dry corn gluten feed. This is likely due to the addition of water soluble carbohydrates in the form of sucrose when sugar beets are included in the mixture, as acid-producing bacteria can use sucrose as a substrate to produce organic acids (Muck, 1988). Alli et al. (1982) noted a similar explanation due to the sucrose levels with sugar cane. Owens et al. (1999) also observed a similar pattern when it was observed that increasing starch in a silage mixture decreased $\mathrm{pH}$. Rapidly attaining a silage $\mathrm{pH}$ below 5.0 is important for feed preservation when making silage (Pitt, 1990), as this inhibits the activity of enzymes that degrade protein (McKersie, 1981), fiber (Dewar et al., 1963), available energy (Muck, 1988; Owens et al., 1999), and helps inhibit mold growth once the silage mixture is exposed to oxygen (Moon, 1983). Our observations indicate that including sugar beets in a silage mixture may assist in attaining a low $\mathrm{pH}$ and quality fermentation.

Concentrations of NDF for treatments $\mathrm{H}, \mathrm{HT}, \mathrm{SBH}$, and SBHT remained similar $(P \geq 0.07)$ 
from d 0 to d 90 , but significantly increased from d 90 to d $180(P \leq 0.01)$. Conversely, concentrations of NDF for treatments.

Table 1. Change in nutrient composition and $\mathrm{pH}$ of silage treatments over time

\begin{tabular}{|c|c|c|c|c|}
\hline \multirow[b]{2}{*}{ Item $^{1}$} & \multicolumn{3}{|c|}{ Day of ensiling ${ }^{2}$} & \multirow[b]{2}{*}{ SEM } \\
\hline & $\mathrm{d} 0$ & $\mathrm{~d} 90$ & d 180 & \\
\hline \multicolumn{5}{|l|}{$\mathrm{H}$} \\
\hline DM & 34.81 & 33.07 & 33.46 & \\
\hline $\mathrm{CP}^{3}$ & 9.63 & 9.99 & 9.92 & 0.13 \\
\hline $\mathrm{NDF}^{3}$ & $61.78^{\mathrm{a}}$ & $63.39^{\mathrm{a}}$ & $69.26^{\mathrm{b}}$ & 0.86 \\
\hline $\mathrm{ADF}^{3}$ & $44.98^{\mathrm{a}}$ & $49.03^{\mathrm{ab}}$ & $52.67^{b}$ & 1.64 \\
\hline $\mathrm{pH}$ & $6.20^{\mathrm{a}}$ & $4.77^{\mathrm{b}}$ & $4.77^{\mathrm{b}}$ & 0.03 \\
\hline \multicolumn{5}{|l|}{ HT } \\
\hline DM & 33.39 & 30.33 & 31.52 & \\
\hline $\mathrm{CP}$ & $10.84^{\mathrm{a}}$ & $11.69^{\mathrm{b}}$ & $12.09^{\mathrm{b}}$ & 0.12 \\
\hline $\mathrm{NDF}$ & $57.35^{\mathrm{a}}$ & $59.58^{\mathrm{a}}$ & $66.78^{b}$ & 0.97 \\
\hline $\mathrm{ADF}$ & $42.69^{\mathrm{a}}$ & $47.25^{\mathrm{ab}}$ & $51.72^{\mathrm{b}}$ & 1.65 \\
\hline $\mathrm{pH}$ & $6.20^{\mathrm{a}}$ & $4.67^{\mathrm{b}}$ & $4.67^{b}$ & 0.03 \\
\hline \multicolumn{5}{|l|}{ SB } \\
\hline DM & 36.17 & 37.32 & 36.07 & \\
\hline $\mathrm{CP}$ & $28.10^{\mathrm{a}}$ & $30.48^{\mathrm{b}}$ & $27.78^{\mathrm{a}}$ & 0.18 \\
\hline $\mathrm{NDF}$ & $10.29^{\mathrm{a}}$ & $15.59^{b}$ & $15.43^{b}$ & 0.48 \\
\hline $\mathrm{ADF}$ & $7.70^{\mathrm{a}}$ & $9.92^{\mathrm{b}}$ & $9.15^{\mathrm{ab}}$ & 0.66 \\
\hline $\mathrm{pH}$ & $6.67^{\mathrm{a}}$ & $4.27^{\mathrm{b}}$ & $4.33^{b}$ & 0.05 \\
\hline \multicolumn{5}{|l|}{ SBT } \\
\hline $\mathrm{DM}$ & 41.40 & 34.09 & 35.35 & \\
\hline $\mathrm{CP}$ & $31.91^{\mathrm{a}}$ & $32.60^{\mathrm{a}}$ & $33.94^{b}$ & 0.14 \\
\hline NDF & $7.48^{\mathrm{a}}$ & $17.45^{\mathrm{b}}$ & $14.78^{b}$ & 0.60 \\
\hline $\mathrm{ADF}$ & $5.99^{\mathrm{a}}$ & $9.89^{b}$ & $9.33^{b}$ & 0.55 \\
\hline $\mathrm{pH}$ & $6.50^{\mathrm{a}}$ & $4.43^{\mathrm{b}}$ & $4.40^{\mathrm{b}}$ & 0.04 \\
\hline \multicolumn{5}{|l|}{ SBH } \\
\hline $\mathrm{DM}$ & 45.08 & 38.91 & 39.05 & \\
\hline $\mathrm{CP}$ & $9.99^{\mathrm{a}}$ & $10.52^{\mathrm{b}}$ & $10.79^{\mathrm{b}}$ & 0.14 \\
\hline NDF & $55.82^{\mathrm{a}}$ & $54.11^{\mathrm{a}}$ & $60.88^{b}$ & 1.10 \\
\hline $\mathrm{ADF}$ & $42.05^{\mathrm{a}}$ & $44.50^{\mathrm{b}}$ & $43.78^{\mathrm{ab}}$ & 0.50 \\
\hline $\mathrm{pH}$ & $5.97^{\mathrm{a}}$ & $4.50^{\mathrm{b}}$ & $4.40^{\mathrm{b}}$ & 0.05 \\
\hline \multicolumn{5}{|l|}{ SBHT } \\
\hline $\mathrm{DM}$ & 43.62 & 43.28 & 41.65 & \\
\hline $\mathrm{CP}$ & 17.22 & 17.34 & 17.13 & 0.12 \\
\hline NDF & $42.87^{\mathrm{a}}$ & $43.40^{\mathrm{a}}$ & $50.17^{\mathrm{b}}$ & 0.91 \\
\hline $\mathrm{ADF}$ & $32.17^{\mathrm{a}}$ & $33.19^{\mathrm{ab}}$ & $34.84^{\mathrm{b}}$ & 0.71 \\
\hline $\mathrm{pH}$ & $6.20^{\mathrm{a}}$ & $4.57^{\mathrm{b}}$ & $4.47^{\mathrm{b}}$ & 0.04 \\
\hline
\end{tabular}

${ }^{1}$ Silage treatments were H: hay; HT: hay with liquid mold inhibitor; SB: sugar beets and soybean meal; SBT: sugar beets and soybean meal with liquid mold inhibitor; SBH: sugar beets and hay; SBHT: sugar beets and hay with liquid mold inhibitor.

${ }^{2} \mathrm{n}=3$ for each treatment per time period.

${ }^{3}$ Percentage on a DM basis.

${ }^{\mathrm{a}, \mathrm{b}}$ Means without common superscript within row differ $(\mathrm{P}<0.05)$ 
SB and SBT significantly increased from d 0 to $\mathrm{d} 90(P \leq 0.01)$ and remained similar from $\mathrm{d}$ 90 to $\mathrm{d} 180(P \geq 0.06)$. It is possible for phenolic products to form as a result of Maillard reactions when the temperature of the silage exceeds $40^{\circ} \mathrm{C}$ (Goering et al., 1973), which would be represented in both NDF and ADF fractions (NRC, 2016). However, the maximum internal temperature among all treatments during the ensiling process was $12^{\circ} \mathrm{C}$. Due to these circumstances, it seems likely that any increase in fiber concentration in this instance would be due to the loss of non-fiber constituents, similar to what was observed by Gunn et al., (2013) when modified wet distillers grains with solubles were ensiled with marginal-quality feedstuffs. The immediate increase in NDF of the SB and SBT treatments was likely due to the abundance of sugar present, which is a readily fermentable carbohydrate that would be utilized rapidly. The delayed increase of NDF of the H, HT, SBH, and SBHT treatments may be due to the hay portion of these mixtures, as hemicellulose would be the primary carbohydrate used by bacteria to produce organic acids, and was not fermented as rapidly as the sugar provided by sugar beets (Dewar et al., 1963). It is reasonable to believe that the utilization of hemicellulose would lead to a decrease in NDF. However, hemicellulose is just one component of NDF, other than cellulose and lignin which are also components of ADF (NRC, 2016). An increase in the proportion of cellulose and lignin could result in an increase in NDF, and this is supported by the observation that ADF also increased in treatments $\mathrm{H}, \mathrm{HT}$, $\mathrm{SBH}$, and SBT $(P \leq 0.05)$. Concentrations of ADF also increased for SB and SBT treatments $(P \leq 0.04)$, also likely due to the sugar that was present being fermented rapidly, thus attributing the increase in ADF concentration to a loss in non-fiber constituents.

Concentrations of $\mathrm{CP}$ did not change with time in $\mathrm{H}$ and SBHT treatments, increased between d 0 and d 90 for the HT treatment $(P \leq 0.02)$, increased between d 90 and d 180 for the SBT treatment $(P \leq 0.02)$, gradually increased from d 0 to $\mathrm{d} 180$ for the SBH treatment $(P \leq 0.03)$, and the SB treatment demonstrated an increase in CP between $\mathrm{d} 0$ and $\mathrm{d} 90(P \leq 0.01)$, then decreased between d 90 an $\mathrm{d} 180(P \leq 0.01)$. The primary factors that affect $\mathrm{CP}$ levels during the ensiling process are $\mathrm{pH}$ (McKersie, 1981), individual species characteristics (Owens et al., 1999), DM concentration (Muck, 1987), and storage temperature (Muck \& Dickerson, 1988). Ambient temperatures and DM concentrations were all similar among treatments throughout the ensiling process, and all $\mathrm{pH}$ values fell within the ideal range to inhibit proteolysis $(3.8-$ 5.0; Pitt, 1990). Increases in CP concentration during the ensiling process are also likely due to a decrease in compounds that do not contain nitrogen, similar to what was observed by Gunn et al., (2003). Although proteolysis is strongly inhibited in an acidic environment (McKersie, 1981), it is still possible that it could occur at a low rate, which may explain the decrease in CP concentrations between d 90 and d 180 of the SB treatment.

Aerobic stability is the amount of time it takes for silage to begin to heat up after the silage is exposed to oxygen (Muck, 2004), which is associated with the presence of aerobic 


\section{Macrothink}

Table 2. Summary of temperature data for the 10 days after opening mini-silos

\begin{tabular}{lrrr} 
& \multicolumn{2}{c}{ Day of ensiling } & \\
\cline { 2 - 3 } Item $^{2}$ & $\mathrm{~d} 90$ & $\mathrm{~d} 180$ & SEM \\
\hline $\mathrm{H}$ & & & \\
$\mathrm{Min},{ }^{\circ} \mathrm{C}$ & $-10.10^{\mathrm{a}}$ & $-1.09^{\mathrm{b}}$ & 1.07 \\
$\mathrm{Max}^{\circ}{ }^{\circ} \mathrm{C}$ & $1.34^{\mathrm{a}}$ & $11.16^{\mathrm{b}}$ & 0.37 \\
$\Delta^{\circ} \mathrm{C} / \mathrm{h}^{3}$ & $0.11^{\mathrm{a}}$ & $0.16^{\mathrm{b}}$ & 0.91
\end{tabular}

HT

$\begin{array}{lrrr}\text { Min, }{ }^{\circ} \mathrm{C} & -7.50^{\mathrm{a}} & 1.46^{\mathrm{b}} & 1.52 \\ \mathrm{Max},{ }^{\circ} \mathrm{C} & 3.62^{\mathrm{a}} & 12.15^{\mathrm{b}} & 0.86 \\ \Delta^{\circ} \mathrm{C} / \mathrm{h} & 0.01 & 0.13 & 1.12\end{array}$

SB

$\begin{array}{lccc}\operatorname{Min},{ }^{\circ} \mathrm{C} & -8.59^{\mathrm{a}} & 2.59^{\mathrm{b}} & 1.60 \\ \mathrm{Max},{ }^{\circ} \mathrm{C} & -0.23^{\mathrm{a}} & 9.55^{\mathrm{b}} & 0.84 \\ \Delta^{\circ} \mathrm{C} / \mathrm{h} & 0.09 & 0.09 & 1.44\end{array}$

SBT

$\begin{array}{lccc}\operatorname{Min},{ }^{\circ} \mathrm{C} & -8.93^{\mathrm{a}} & 1.64^{\mathrm{b}} & 1.61 \\ \mathrm{Max},{ }^{\circ} \mathrm{C} & -0.20^{\mathrm{a}} & 9.54^{\mathrm{b}} & 1.50 \\ \Delta^{\circ} \mathrm{C} / \mathrm{h} & 0.11 & 0.10 & 1.56\end{array}$

$\mathrm{SBH}$

$\begin{array}{lrrr}\operatorname{Min},{ }^{\circ} \mathrm{C} & -7.27^{\mathrm{a}} & 1.20^{\mathrm{b}} & 1.58 \\ \mathrm{Max},{ }^{\circ} \mathrm{C} & 3.81^{\mathrm{a}} & 11.14^{\mathrm{b}} & 0.73 \\ \Delta^{\circ} \mathrm{C} / \mathrm{h} & 0.18 & 0.16 & 1.12\end{array}$

SBHT

\begin{tabular}{lrrr} 
Min, ${ }^{\circ} \mathrm{C}$ & $-6.91^{\mathrm{a}}$ & $2.31^{\mathrm{b}}$ & 1.68 \\
$\mathrm{Max},{ }^{\circ} \mathrm{C}$ & $3.66^{\mathrm{a}}$ & $11.13^{\mathrm{b}}$ & 0.73 \\
$\Delta^{\circ} \mathrm{C} / \mathrm{h}$ & 0.13 & 0.11 & 1.15 \\
\hline
\end{tabular}

${ }^{1}$ Silage treatments were H: hay; HT: hay with liquid mold inhibitor; SB: sugar beets and soybean meal; SBT: sugar beets and soybean meal with liquid mold inhibitor; SBH: sugar beets and hay; SBHT: sugar beets and hay with liquid mold inhibitor.

${ }^{2} \mathrm{n}=3$ for each treatment per time period.

${ }^{3}$ Difference between minimum and maximum divided by the number of hours that transpired. a,b Means without common superscript within row differ $(P<0.05)$.

microorganisms (Woolford, 1990). There seems to be confusion regarding the measurement of aerobic stability among relative literature. Muck (2004) measured aerobic stability by observing how long it takes for the internal temperature of the silage to reach $2{ }^{\circ} \mathrm{C}$ above ambient temperature after exposing the silage to oxygen. Gunn et al., (2013) measured aerobic stability by observing how long it takes for the internal temperature of the silage to obtain an increase in $2^{\circ} \mathrm{C}$ after exposing the silage to oxygen. For this study, we measured aerobic stability by recording the minimum and maximum temperatures during the 10-day period after opening the mini silo's, then calculated a rate of temperature change $\left(\Delta^{\circ} \mathrm{C} / \mathrm{h}\right)$ to represent aerobic stability. All temperature data is represented in Table 2. The liquid mold 
Table 3. Effects of ensiling on the absolute rate of in situ disappearance and density

\begin{tabular}{|c|c|c|c|c|c|c|c|}
\hline Item & & $\mathrm{H}$ & HT & SBH & SBHT & SB & SBT \\
\hline \multicolumn{8}{|c|}{ Absolute rate of disappearance, $\%$ DM disappeared/h } \\
\hline $\mathrm{d} 0$ & & 0.702 & 0.714 & 0.686 & 0.814 & $1.907^{\mathrm{ab}}$ & $1.968^{\mathrm{e}}$ \\
\hline d 90 & & 0.668 & 0.673 & 0.715 & 0.788 & $1.986^{\mathrm{a}}$ & $1.981^{\mathrm{e}}$ \\
\hline d 180 & & 0.647 & 0.653 & 0.699 & 0.783 & $1.860^{\mathrm{b}}$ & $1.745^{\mathrm{f}}$ \\
\hline & SEM & 0.0203 & 0.0220 & 0.0208 & 0.0122 & 0.0327 & 0.0506 \\
\hline & $P$-value ${ }^{2}$ & 0.23 & 0.17 & 0.64 & 0.23 & 0.09 & 0.03 \\
\hline \multicolumn{8}{|c|}{ Density, $\mathrm{kg} / \mathrm{m}^{3}$} \\
\hline d 0 & & - & - & - & - & - & - \\
\hline d 90 & & 261.81 & 270.01 & $544.01^{\mathrm{e}}$ & 548.36 & 267.67 & 254.34 \\
\hline \multirow[t]{3}{*}{ d 180} & & 261.83 & 273.80 & $578.84^{\mathrm{f}}$ & 545.10 & 272.21 & 253.77 \\
\hline & SEM & 6.340 & 6.147 & 9.071 & 8.987 & 4.306 & 5.202 \\
\hline & $P$-value ${ }^{2}$ & 1.00 & 0.67 & $<0.01$ & 0.72 & 0.38 & 0.94 \\
\hline
\end{tabular}

${ }^{1}$ Silage treatments were H: hay; HT: hay with liquid mold inhibitor; SB: sugar beets and soybean meal; SBT: sugar beets and soybean meal with liquid mold inhibitor; SBH: sugar beets and hay; SBHT: sugar beets and hay with liquid mold inhibitor.

${ }^{2} P$-value for day within ensiling mixture and ultra

${ }^{\mathrm{a}, \mathrm{b}}$ Means without a common superscript within column tend to differ $(P<0.10)$

${ }^{\mathrm{e}, \mathrm{f}}$ Means without a common superscript within column differ $(P<0.05)$

inhibitor reduced the rate of temperature change during the 10 days following the opening of the silos for all treatments except for the SB treatment. Organic acids present when silage becomes exposed to oxygen can help inhibit yeast and mold growth. Acetic and propionic acid have demonstrated to be better inhibitors of yeast and mold than lactic acid (Moon, 1983). It was expected that the SB treatment in particular would benefit from the inoculant, due to relevant scientific literature reporting an increase in lactic acid and a decrease in acetic acid when sugar beet pulp is ensiled (Ferris and Mayne, 1994; Moore and Kennedy, 1994). However, since the energy contained in sugar beets is more readily available than the energy in hay, it's possible that the naturally occurring bacteria established a healthy population more rapidly than the bacterial population that was intended to be established by using a liquid mold inhibitor. This is considered to be one of the primary reasons as to why mold inhibiting inoculants do not always improve aerobic stability (Muck, 1988).

In situ results are represented in Table 3 and in Table 4. Absolute rate of in -situ disappearance did not differ between d 0, 90, and 180 for treatments H, HT, SBH, and SBHT. However, SBT demonstrated a decrease in rate of in -situ disappearance between d 90 and $\mathrm{d}$ $180(P=0.03)$, and SB demonstrated a tendency to decrease rate of in-situ disappearance between $\mathrm{d} 90$ and $\mathrm{d} 180(P=0.09)$. The decrease in in-situ disappearance that was observed with SB and SBT is likely attributable to the increase in fiber concentration that was observed throughout the ensiling process. Despite the observed decrease in in-situ disappearance, SB and SBT demonstrated the highest disappearance rates at all time-points relative to other treatments. This is not surprising, as the in vitro dry matter digestibility (IVDMD) of sugar beet pulp is approximately $75 \%$, which is much greater than the IVDMD of hay 
Table 4. Impacts of ensiling sugar beets, liquid mold inhibitor, and day on in-situ disappearance

\begin{tabular}{|c|c|c|c|c|c|c|}
\hline \multirow[b]{2}{*}{ Hour } & \multicolumn{6}{|c|}{ Treatment $^{1}$} \\
\hline & $\mathrm{H}$ & HT & SBH & SBHT & SB & SBT \\
\hline \multicolumn{7}{|l|}{ d 0} \\
\hline 0 & 20.64 & 22.37 & 25.63 & 30.93 & 53.88 & 49.50 \\
\hline 2 & - & - & 32.36 & $40.89^{a}$ & 59.30 & 55.62 \\
\hline 4 & - & - & 32.18 & 38.22 & 60.19 & 55.27 \\
\hline 6 & 27.66 & 27.97 & 32.96 & 38.94 & 62.44 & 58.77 \\
\hline 12 & 31.11 & 32.73 & 36.47 & 44.62 & 67.61 & 61.56 \\
\hline 24 & $38.37^{\mathrm{ab}}$ & 40.32 & $41.43^{\mathrm{a}}$ & 50.48 & $76.63^{\mathrm{a}}$ & $70.91^{\mathrm{a}}$ \\
\hline 48 & 52.47 & 49.72 & 54.91 & 67.55 & $91.51^{\mathrm{ab}}$ & $94.46^{\mathrm{a}}$ \\
\hline 72 & $65.18^{\mathrm{a}}$ & $66.95^{\mathrm{a}}$ & 64.47 & $77.22^{\mathrm{a}}$ & - & - \\
\hline 96 & $67.39^{\mathrm{a}}$ & $68.52^{\mathrm{a}}$ & 65.88 & 78.17 & - & - \\
\hline \multicolumn{7}{|l|}{ d 90} \\
\hline 0 & 18.41 & 19.57 & 26.01 & 27.79 & 49.55 & 44.74 \\
\hline 2 & - & - & 31.27 & $32.26^{\mathrm{b}}$ & 56.50 & 53.19 \\
\hline 4 & - & - & 33.56 & 34.73 & 56.62 & 54.38 \\
\hline 6 & 24.11 & 24.94 & 33.03 & 35.46 & 58.95 & 56.07 \\
\hline 12 & 27.72 & 30.82 & 36.48 & 41.12 & 67.19 & 64.55 \\
\hline 24 & $35.70^{\mathrm{a}}$ & 39.17 & $44.79^{\mathrm{ab}}$ & 52.65 & $84.54^{\mathrm{b}}$ & $85.62^{\mathrm{b}}$ \\
\hline 48 & 52.19 & 53.24 & 59.19 & 67.59 & $95.30^{\mathrm{a}}$ & $95.10^{\mathrm{a}}$ \\
\hline 72 & $59.76^{\mathrm{b}}$ & $61.66^{\mathrm{b}}$ & 65.32 & $72.14^{\mathrm{b}}$ & - & - \\
\hline 96 & $64.07^{\mathrm{ab}}$ & $64.56^{\mathrm{ab}}$ & 68.62 & 75.62 & - & - \\
\hline \multicolumn{7}{|l|}{ d 180} \\
\hline 0 & 18.96 & 19.22 & 28.32 & 31.45 & 49.20 & 44.67 \\
\hline 2 & - & - & 33.66 & $37.07^{\mathrm{ab}}$ & 58.73 & 52.99 \\
\hline 4 & - & - & 32.53 & 36.50 & 57.59 & 51.97 \\
\hline 6 & 24.68 & 26.53 & 34.36 & 38.06 & 60.97 & 54.63 \\
\hline 12 & 30.78 & 31.86 & 36.90 & 45.08 & 65.49 & 60.72 \\
\hline 24 & $41.03^{\mathrm{b}}$ & 43.00 & $47.88^{\mathrm{b}}$ & 54.12 & $74.91^{\mathrm{a}}$ & $71.09^{\mathrm{a}}$ \\
\hline 48 & 55.41 & 53.77 & 58.99 & 66.67 & $89.29^{b}$ & $83.73^{\mathrm{b}}$ \\
\hline 72 & $56.75^{\mathrm{b}}$ & $59.21^{\mathrm{b}}$ & 62.74 & $69.16^{\mathrm{b}}$ & - & - \\
\hline 96 & $62.09^{\mathrm{b}}$ & $62.71^{\mathrm{b}}$ & 67.08 & 75.17 & - & - \\
\hline SEM & \multicolumn{2}{|c|}{1.645} & \multicolumn{2}{|c|}{1.980} & \multicolumn{2}{|c|}{2.129} \\
\hline$P$-value & \multicolumn{2}{|c|}{$<0.01$} & \multicolumn{2}{|c|}{$<0.01$} & \multicolumn{2}{|c|}{$<0.01$} \\
\hline
\end{tabular}

${ }^{1}$ Silage treatments were H: hay; HT: hay with liquid mold inhibitor; SB: sugar beets and soybean meal; SBT: sugar beets and soybean meal with liquid mold inhibitor; SBH: sugar beets and hay; SBHT: sugar beets and hay with liquid mold inhibitor.

${ }^{\mathrm{a}, \mathrm{b}}$ Means within the same hour and treatment without a common superscript differ $(P<0.05)$.

(approximately 54\%; Sanson, 1993). Additionally, soybean meal is rapidly degraded within the rumen, leading to the increased rate and extent of the SB and SBT samples. Ensiling of the sugar beets aided in storage viability without negatively altering digestibility.

\section{Conclusions}

In conclusion, our data implies that sugar beets can be ensiled with hay or soybean meal without inducing any deleterious effects on nutrient composition or preservation characteristics. Therefore, sugar beet producers have a potential outlet for unharvested sugar beets in livestock producers and livestock producers may prolong the storage viability of sugar beets through the ensiling process. Ensiled sugar beets with soybean meal or hay may provide an economical and prolonged feed source for livestock producers during the fall and winter months. Additional considerations for ensiling sugar beets should include labor and equipment costs of the ensiling process and the product potential as a feedstuff. Due to the 
moisture content of the sugar beets, minimizing travel from the field to the ensiling area may be more economical. Furthermore, more research is needed to determine the viability of ensiled sugar beets on a large scale for both ensiling properties and as a livestock feed source.

\section{Acknowledgements}

Funding for these projects was provided by USDA Hatch Funds. The authors would like to thank Dr. Ken Kephart, Southern Agricultural Research Center, for the sugar beets for these trials.

\section{References}

Alli, I., Baker, B. E., \& Garcia, G. (1982). Studies on the fermentation of chopped sugarcane. Animal Feed Science and Technology, 7(4), 411-417. https://doi.org/10.1016/0377-8401(82)90010-4

AOAC. (2005). Official Methods of Analysis (18 ${ }^{\text {th }}$ ed.). Association of Analytical Communities, Arlington, VA.

AOAC. (2010). Official Methods of Analysis (17 $7^{\text {th }}$ ed.). Association of Analytical Communities, Arlington, VA.

Cherney, D. J. R., Cherney, J. H., \& Cox, W. J. (2004). Fermentation characteristics of corn forage ensiled in mini-silos. Journal of Dairy Science,87(12), 4238-4246. https://doi.org/10.3168/jds.S0022-0302(04)73569-9

Dewar, W. A., McDonald, P., \& Whittenbury, R. (1963). The hydrolysis of grass hemicelluloses during ensilage. Journal of the Science of Food and Agriculture, 14, 411-417. https://doi.org/10.1002/jsfa.2740140610

Ferris, C. P., \& Mayne, C. S. (1994). The effects of incorporating sugar-beet pulp with herbage at ensiling on silage fermentation, effluent output and in-silo losses. Grass and Forage Science, 49(2), 216-228. https://doi.org/10.1111/j.1365-2494.1994.tb01995.x

Goering, H. K., Van Soest, P. J., \& Hemken, R. W. (1973). Relative susceptibility of forages to heat damage as affected by moisture, temperature, and pH. Journal of Dairy Science, 56(1), 137-143. https://doi.org/10.3168/jds.S0022-0302(73)85127-6

Gunn, P. J., Buckmaster, D. R., Lemenager, R. P., Van Emon, M. L., Claeys, M. C., \& Lake, S. L. (2013). Preservation characteristics of modified wet distillers grains with solubles stored with marginal-quality feedstuffs in laboratory-scale mini silos. The Professional Animal Scientist, 29(6), 671-676. https://doi.org/10.15232/S1080-7446(15)30299-0

Lardy, G., \& Schafer, R. (2008). Feeding sugar beet byproducts to cattle. NDSU Extension Service. AS-1365.

Leupp, J. L., Encinias, A. M., Bauer, M. L., Caton, J. S., Gilbery, T. C., Carlson, J., \& Lardy, G. P. (2006). Ensiling properties of wet sugarbeet pulp and the addition of dry feedstuffs. Journal of Sugar Beet Research, 43(3), 99.

McGregor, I., Page, C. M., Ryan, C., Hubbard, A. R., Manoukian, M., Stewart, W. C., \& Van Emon, M. L. (2017). The effects of shredded sugar beets on sheep nutrient metabolism and ruminal characteristics. Trans. Anim. Sci., 75-80.

McGregor, I., Page, C. M., Stewart, W. C., \& Van Emon, M. L. (2016, December). Effects of increasing sugar beets on steer backgrounding performance. In Proc. West. Sec. Amer. Soc. 
Anim. Sci., 67.

McKersie, B. D. (1981). Proteinases and peptidases of alfalfa herbage. Canadian Journal of Plant Science, 61(1), 53-59. https://doi.org/10.4141/cjps81-008

Moon, N. J. (1983). Inhibition of the growth of acid tolerant yeasts by acetate, lactate and propionate and their synergistic mixtures. Journal of applied Bacteriology, 55(3), 453-460. https://doi.org/10.1111/j.1365-2672.1983.tb01685.x

Moore, C. A., \& Kennedy, S. J. (1994). The effect of sugar beet pulp-based silage additives on effluent production, fermentation, in-silo losses, silage intake and animal performance. Grass and Forage $\quad$ Science, 49(1), 54-64. https://doi.org/10.1111/j.1365-2494.1994.tb01976.x

Muck, R. E. (1987). Dry matter level effects on alfalfa silage quality I. Nitrogen transformations. Transactions of the ASAE, 30(1), 7-0014. https://doi.org/10.13031/2013.30393

Muck, R. E. (1988). Factors influencing silage quality and their implications for management. Journal of Dairy Science, 71(11), $\quad$ 2992-3002. https://doi.org/10.3168/jds.S0022-0302(88)79897-5

Muck, R. E. (2002). Effects of corn silage inoculants on aerobic stability. In 2002 ASAE Annual Meeting (p. 1). American Society of Agricultural and Biological Engineers.

Muck, R. E., \& Dickerson, J. T. (1988). Storage temperature effects on proteolysis in alfalfa silage. Transactions of the ASAE, 31(4), 1005-1009. https://doi.org/10.13031/2013.30813

NRC. (2016). Nutrient requirements of beef cattle (8th ed.). Washington, DC: Natl. Acad. Press. Owens, V. N., Albrecht, K. A., Muck, R. E., \& Duke, S. H. (1999). Protein degradation and fermentation characteristics of red clover and alfalfa silage harvested with varying levels of total nonstructural carbohydrates. Crop $\quad$ Science, 39(6), 1873-1880. https://doi.org/10.2135/cropsci1999.3961873x

Pitt, R. E. (1990). Silage and hay preservation. NRAES-5. Northeast Reg. Agric. Eng. Service, Ithaca, NY.

USDA. (2015a). Montana agricultural statistics. Volume LII. Retrieved from https://www.nass.usda.gov/Statistics_by_State/Montana/Publications/Annual_Statistical_Bull etin/2015/Montana_Annual_Bulletin_2015.pdf. (Accessed 18 March 2016.)

USDA. (2015b). U.S. sugarbeet crops: area planted, acres harvested, yield per acre, and production by state and region. Retrieved from http://www.ers.usda.gov/datafiles/Sugar_and_Sweeteners_Yearbook_Table/US_Sugar_Suppl y_and_Use/TABLE14.XLS. (Accessed 18 March 2016.)

Woolford, M. K. (1990). The detrimental effects of air on silage. Journal of Applied Bacteriology, 68(2), 101-116.

\section{Copyright Disclaimer}

Copyright for this article is retained by the author(s), with first publication rights granted to the journal.

This is an open-access article distributed under the terms and conditions of the Creative Commons Attribution license (http://creativecommons.org/licenses/by/4.0/). 